\title{
A phase II open-label multicenter study of gefitinib in combination with irradiation followed by chemotherapy in patients with inoperable stage III non-small cell lung cancer
}

\author{
Antonin Levy ${ }^{1,2,3}$, Etienne Bardet ${ }^{4}$ Benjamin Lacas ${ }^{5,6}$, Jean-Pierre Pignon ${ }^{5,6}$, \\ Julien Adam ${ }^{7}$, Ludovic Lacroix ${ }^{7}$, Xavier Artignan ${ }^{8,10}$, Pierre Verrelle $^{9}$ and Cécile Le \\ Péchoux ${ }^{1}$ \\ ${ }^{1}$ Department of Radiation Oncology, Gustave Roussy, Université Paris-Saclay, Institut Thoracique d'Oncologie (IOT), Villejuif, \\ France \\ 2 INSERM U1030, Molecular Radiotherapy, Gustave Roussy, Université Paris-Saclay, Villejuif, France \\ ${ }^{3}$ Univ Paris Sud, Université Paris-Saclay, Le Kremlin-Bicêtre, France \\ ${ }^{4}$ Department of Medical Oncology, Institut de Cancérologie de l'Ouest, Nantes, France \\ ${ }^{5}$ Gustave Roussy, Université Paris-Saclay, Department of Biostatistics and Epidemiology, Villejuif, France \\ ${ }^{6}$ INSERM U1018, CESP, Université Paris-Sud, Université Paris-Saclay, Villejuif, France \\ 7 Department of Medical Biology and Pathology, Translational Research Laboratory and Biobank (UMS3655 CNRS / US23 \\ INSERM), INSERM Unit U981, Villejuif, France \\ ${ }^{8}$ Department of Radiation Oncology, University Hospital Grenoble, Grenoble, France \\ ${ }^{9}$ Department of Radiation Oncology, Centre Jean Perrin, Clermont-Ferrand, France \\ 10 Department of Radiation Oncology, St Grégoire Hospital, St Grégoire, France \\ Correspondence to: Cécile Le Péchoux, email: cecile.lepechoux@gustaveroussy.fr
} Keywords: iressa, thoracic radiotherapy, lung cancer, phase II trial

Received: July 06, $2016 \quad$ Accepted: October 12, $2016 \quad$ Published: October 18, 2016

\section{ABSTRACT}

Background: Gefitinib is an oral EGFR tyrosine kinase inhibitors which may act as a radiosensitizer.

Patients and Methods: This phase II study evaluated the efficacy of gefitinib $\mathbf{2 5 0}$ mg once daily in combination with thoracic radiotherapy (66 Gy in 6.5 weeks, 2 Gy/ day, 5 fractions/week) followed by consolidation chemotherapy (IV cisplatin and vinorelbine) as first line treatment in a population of unselected stage IIIB NSCLC patients according to EGFR mutation status.

Results: Due to a low accrual rate in this study, the sample size $(n=50)$ was not reached. Sixteen patients were included in four centers, $50 \%$ had adenocarcinoma and $75 \%$ were male. Genomic alterations ( 7 patients studied) retrieved TP53 mutation in 2 patients and no EGFR mutation. Four weeks after radiotherapy, 3 patients (19\%) had a partial response, $6(38 \%)$ had a stable disease, and 7 had a progression (44\%). Median overall survival was 11 months and median progression-free survival was 5 months. At the time of the last contact, 5 patients $(31 \%)$ were still alive. Main toxicities were gastrointestinal $(81 \%)$, cutaneous $(81 \%)$, general $(56 \%)$, and respiratory (50\%). There were $12>\mathrm{G} 3$ adverse events in $7(47 \%)$ patients, and there was one toxic-death during the concomitant period due to an interstitial pneumonitis. There were two possible adverse events-related deaths during the chemotherapy period (pulmonary embolism $(n=1)$ and sudden death after the administration of the $3^{\text {rd }}$ course of chemotherapy $(n=1)$ ).

Conclusion: The benefit of Gefitinib-RT could not be confirmed due to premature trial discontinuation. Further evaluation is required, especially in patients with EGFR mutated NSCLC. 


\section{INTRODUCTION}

The standard treatment for locally advanced unresectable non-small cell lung cancer (NSCLC) is the association of conventional chemotherapy (platinum based doublets) and radiotherapy [1-3]. Outcomes of locally advanced NSCLC however remain poor and new efficient, safe, and more specific treatments are needed. In the last decades, an enhanced understanding of the NSCLC oncogenic molecular pathways has led to the expansion of individualized targeted therapies. Molecular anomalies include KRAS mutation and / or mutation and overexpression of epidermal growth factor receptor $(E G F R)$. Mutations in the EGFR tyrosine kinase are observed in approximately in $15 \%$ to $62 \%$ of patients and are predictors of responsiveness to EGFR tyrosine kinase inhibitors (TKIs) [4-7]. In the metastatic setting, several EGFR TKIs (erlotinib, gefitinib, afatinib) prolong progression-free survival as compared with platinum based chemotherapy doublets in patients with EGFR mutated lung cancer [5].

Gefitinib (iressa $^{\mathrm{TM}}$, ZD1839) is an oral EGFR TKI indicated for the treatment of adult patients with locally advanced/metastatic NSCLC with activating mutations of EGFR [6,7]. Preclinical evidence suggests that gefitinib enhanced the radioresponse of NSCLC cells by suppressing cellular DNA repair [8]. Concomitant use of EGFR inhibitor and radiotherapy has also demonstrated a significantly increased overall survival (OS) as compared with radiotherapy alone in one randomized controlled trial in head and neck cancer [9]. In light of these data, we conducted a phase II trial that aimed to evaluate the efficacy of gefitinib associated with irradiation, followed by chemotherapy in patients with inoperable stage III NSCLC.

\section{PATIENTS AND METHODS}

\section{Eligibility criteria}

Patients ( $\geq 18$ years) were eligible for inclusion if they had histologically confirmed unresectable nonpretreated stage III NSCLC. Additional inclusion criteria were: at least one measurable lesion according to Response Evaluation Criteria In Solid Tumors (RECIST version 1.0); World Health Organisation (WHO) performance status (PS) of 0 to 2 at inclusion; adequate pulmonary function (forced expiratory volume in 1 second $\left[\mathrm{FEV}_{1}\right]$ is greater than or equal to $1 \mathrm{~L}$, oxygen diffusion capacity of greater than or equal to $40 \%$ ); pulmonary dose volume histogram V20Gy inferior or equal to $40 \%$; life expectancy of at least 6 months; Female patients could be included if use of secure contraceptive precautions, or post-menopausal. Exclusion criteria were: prior anticancer treatment (including thoracic radiotherapy or anti-EGFR therapy); known hypersensitivity to gefitinib, cisplatin or vinorelbine, or any of the excipients of these product; interstitial lung disease; malignancies diagnosed within the last 5 years; severe coexisting, psychological, or uncontrolled condition; documented or symptomatic metastases, including positive cytology in the case of pleural effusion; pregnancy or breast feeding; concomitant use of inhibitors of CYP3A4; and weight loss of over $15 \%$ in the 3 months before the start of the study. ${ }^{18} \mathrm{~F}$-fluorodeoxyglucose positron emission tomography $\left({ }^{18} \mathrm{~F}\right.$-FDG PET/CT) and brain magnetic resonance imaging (MRI) were not mandatory for patient inclusion.

\section{Study design and treatments}

This was a phase II, multicenter, open-label, onearm study in patients with inoperable histologically confirmed stage III NSCLC to explore the efficacy of $250 \mathrm{mg}$ gefitinib administered concurrently with thoracic radiotherapy followed by chemotherapy.

Gefitinib $250 \mathrm{mg}$ was administered orally once daily beginning 7 days before the onset of radiotherapy, until the end of radiotherapy, disease progression, unacceptable toxicity or withdrawal of consent. Conformal thoracic radiotherapy was delivered at the total dose of $66 \mathrm{~Gy}$ in 33 daily fractions of $2 \mathrm{~Gy}$, over a 45 -day period. There were no time constraints between staging procedures and start of treatment. Four weeks after completion of gefitinib and radiotherapy, patients received 3 cycles of chemotherapy combining intravenous cisplatin (100 $\mathrm{mg} / \mathrm{m}^{2}$ once every 28 days) and vinorelbine $\left(25 \mathrm{mg} / \mathrm{m}^{2}\right.$ once per week for 3 weeks out of 4). We chose cisplatinvinorelbine doublet for its good efficacy/toxicity profile when delivered sequentially to thoracic radiotherapy [10, 11]. Patients were assessed one month after the completion of the experimental combination and one month after the last chemotherapy cycle with physical examination and imaging studies. The study was approved by the relevant ethics committee/institutional review board and was conducted in compliance with the Declaration of Helsinki as well as good clinical practice guidelines. Written informed consent was obtained from all patients before trial initiation. This study is registered with ClinicalTrials. gov, number NCT00333294.

\section{Molecular analysis}

As planned in the study, formalin-fixed, paraffinembedded material from baseline biopsy was evaluated for Ki67, phospho(p)ERK, pAKT, EGFR, and pEGFR expression using immunohistochemistry (IHC).

Genomic analysis was performed in the accessible samples. The mutational status of specific cancer genes was determined using next generation sequencing based 
Table 1: Patients' baseline characteristics at inclusion Characteristics

Age (years) ${ }^{*}$

Gender

Male

Female

WHO PS score

0

1

2

Tobacco

Yes

No

Histology of primary tumor

Squamous

Adenocarcinoma

Others
$55.5(43-70)$

$12(75)$

$4(25)$

$8(50)$

7 (44)

$1(6)$

$11(69)$

$5(31)$

$6(37)$

$8(50)$

$2(13)$

TNM classification (Stage IIIB: $\mathrm{n}=16$ )

T2N3M0

$1(6)$

$3(19)$

$5(31)$

$4(25)$

T4N3M0

Pulmonary Function Testing ${ }^{*}$

FEV1 (liter)

$2.3(1.3-3.4)$

$70(47-103)$

* Median (range)

WHO PS: World Health Organisation performance status; N: number of patients; FEV1: Forced Expiratory

Volume in one second; DLCO: diffusing capacity for carbon monoxide ; $\%$ theo: $\%$ of the theoretical value.

onIon Torrent approach with Ampliseq Cancer Hotspot panelV2 (Lifetechnologie, Darmstadt, Germany) library preparation as previously described [12].

Molecular analysis was an exploratory objective of this study, and it was not mandatory to have enough tissue available for translational research.

\section{Endpoints and statistical considerations}

The primary endpoint was objective response rate (complete response [CR] and partial response [PR]) 4 weeks after completion of gefitinib and irradiation (immediately prior to chemotherapy), based on the RECIST criteria on computed tomography. Secondary endpoints included: objective response rate at study closure, incidence of controlled disease (CR, PR and stable disease $[\mathrm{SD}]$ ) at study closure, progression-free survival
(PFS), duration of response, overall survival (OS), and safety variables (acute and late toxicity graded according to Common Terminology Criteria for Adverse Events v3.0 [CTCAE], adverse events [AEs], drug interruptions, and study drug exposure).

Fleming's method was used to calculate the number of patients required. A sample size of 50 patients was sufficient to have a power of $80 \%$ to detect an objective response rate of $60 \%$ and $78 \%$ as null and alternative hypothesis respectively, with an alpha of 5\% (onesided). If 37 or more responses were observed out of the 50 patients, it would be possible to conclude in favour of the efficacy of the treatment. All patients that were enrolled and received trial drug were considered the intention-to-treat (ITT) population.

OS and PFS were estimated using the Kaplan-Meier method and defined as the time between inclusion and death from any cause for OS, death or tumor progression 
for PFS, or last follow-up for surviving patients, whichever came first. Median follow-up was calculated according to Schemper's method [13]. Statistical analyses were performed using SAS (version 9.3). All reported p-values are two-sided, and p-values lower than 0.05 were considered significant.

\section{RESULTS}

\section{Trial conduct}

A total of 16 (/22 screened) patients with stage IIIB NSCLC were enrolled in 4 French centers between $09 / 2004$ and $01 / 2006$. Due to a low accrual rate in this study, the sample size was not reached and the study was prematurely closed.

Table 1 lists the main characteristics of the study population. Most patients were males (75\%) and the median age was 56 years old (range, 43-70 years). Immunohistochemistry analysis of the tumor was performed for 10 patients (Ki67, pERK, pAKT, EGFR and pEGFR). Two, 2, and 4 patients had positive biopsies for pERK, pAKT, and EGFR, respectively. All patients had low Hirsch scores for pEGFR and median Ki67 proliferation index was $40 \%$ (range, 5-90\%). Since response to EGFR TKIs relies on mutational status, a genomic analysis was performed on accessible samples. Genomic alterations ( $n=7$ analyzed, others biopsies not available/assessable) retrieved TP53 mutation in 2 patients and no EGFR mutation. There were 3 patients without retrieved alteration, and 2 without detectable DNA. Other samples were not accessible or not assessable.

\section{Treatment delivery}

Compliance with gefitinib was good: all patients received the entire planned treatment except six interruptions (corresponding to more than $85 \%$ of the initial planned dose): four temporary and two patients did not resume the treatment (disease progression: $n=$ 1; asthenia: $n=1$ ). No dose reduction of gefitinib was allowed. The median duration of gefitinib exposure was 55 days (range, 32-65 days).

All patients but two received the entire planned radiotherapy. The median dose delivered was $60 \mathrm{~Gy}$ (range, 40-66 Gy) in 30 fractions (range, 20-33) with a median duration of 48.5 days (range, 30-57 days) with $3 \mathrm{D}$-conformal radiotherapy ( $n=16$; no used intensity modulated radiation therapy [IMRT] or respiratory gating).

Consolidation chemotherapy was delivered 10 patients and 7/10 patients received the three initially planned cycles of cisplatin and vinorelbine. Five/7 patients had a dose reduction ( $8 \%$ of the initially planned dose) from the second cycle.

The median duration of the overall treatment was 132 days (range, 38-165 days). However, even if compliance was good, 10 out of 16 patients $(63 \%)$ withdrew prematurely from study: one due to an adverse event (G3 hemoglobin decrease during the $2^{\text {nd }}$ cycle of chemotherapy), and others due to cancer related-disease progression or death (two during radiotherapy, four after

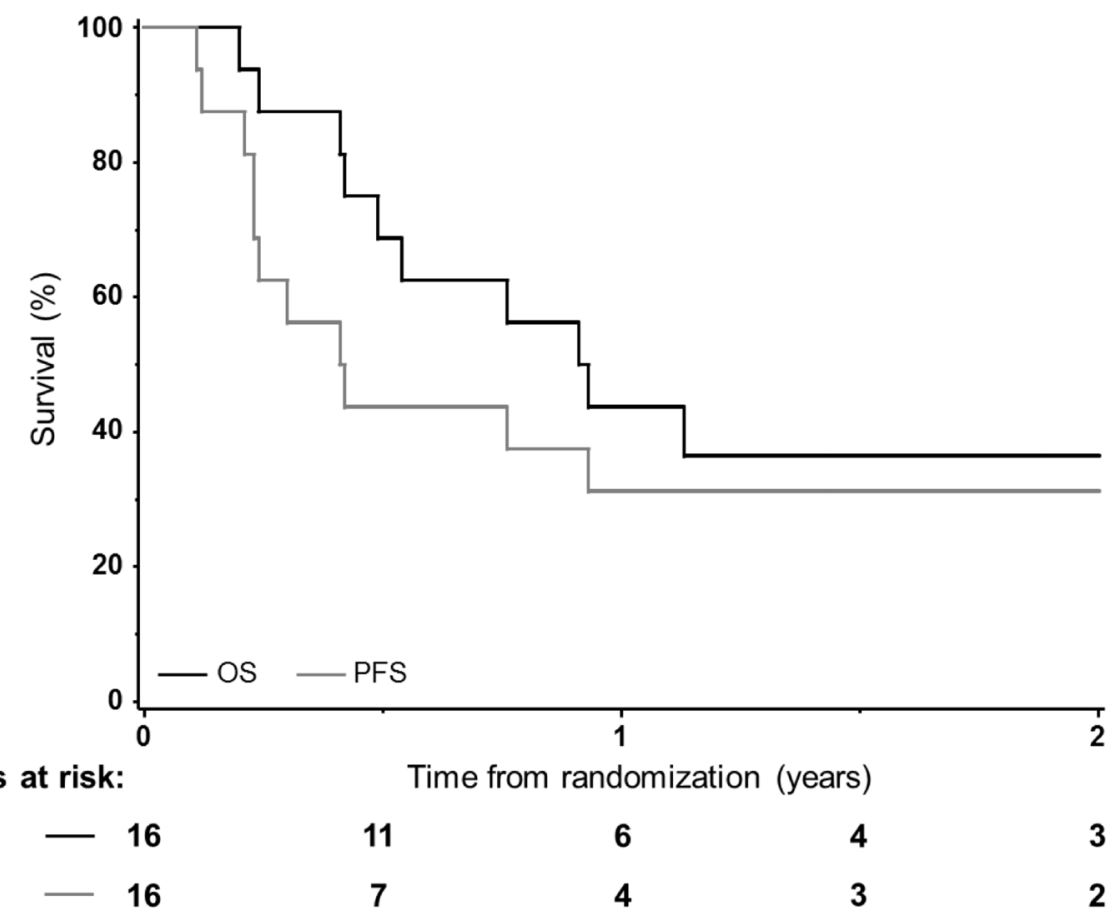

Figure 1: Overall (OS) and progression-free survivals (PFS) among the 16 patients 
Table 2: Most common AEs ( $>10 \%$ of patients overall) observed in 16 patients during the combination of gefitinib and radiotherapy (weeks 1-11)

\begin{tabular}{|c|c|c|}
\hline Toxicity & $\begin{array}{l}\text { Number of patients } \\
\mathbf{N}(\%)\end{array}$ & $\begin{array}{l}\text { AEs } \\
\mathbf{N}\end{array}$ \\
\hline Gastrointestinal disorders & $13(81.3 \%)$ & 34 \\
\hline Nausea & $7(43.8 \%)$ & 9 \\
\hline Diarrhea & $6(37.5 \%)$ & 7 \\
\hline Esophagitis & $4(25.0 \%)$ & 4 \\
\hline Vomiting & $4(25.0 \%)$ & 6 \\
\hline Dysphagia & $2(12.5 \%)$ & 2 \\
\hline Stomatitis & $2(12.5 \%)$ & 2 \\
\hline Skin disorders & $13(81.3 \%)$ & 16 \\
\hline Dermatitis & $5(31.3 \%)$ & 5 \\
\hline Rash & $4(25.0 \%)$ & 4 \\
\hline Erythema & $3(18.8 \%)$ & 3 \\
\hline General disorders & $9(56.3 \%)$ & 21 \\
\hline Chest pain & $4(25.0 \%)$ & 4 \\
\hline Fatigue & $3(18.8 \%)$ & 5 \\
\hline Asthenia & $2(12.5 \%)$ & 3 \\
\hline Mucosal inflammation & $2(12.5 \%)$ & 2 \\
\hline Pyrexia & $2(12.5 \%)$ & 4 \\
\hline Respiratory disorders & $8(50.0 \%)$ & 12 \\
\hline Cough & $4(25.0 \%)$ & 4 \\
\hline Investigations & $7(43.8 \%)$ & 12 \\
\hline ALT increased & $3(18.8 \%)$ & 3 \\
\hline AST increased & $3(18.8 \%)$ & 3 \\
\hline Weight decreased & $2(12.5 \%)$ & 2 \\
\hline Metabolism and nutrition disorders & $6(37.5 \%)$ & 8 \\
\hline Anorexia & $4(25.0 \%)$ & 4 \\
\hline Dehydration & $2(12.5 \%)$ & 2 \\
\hline Nervous system disorders & $5(31.3 \%)$ & 7 \\
\hline Headache & $2(12.5 \%)$ & 4 \\
\hline Vascular disorders & $5(31.3 \%)$ & 6 \\
\hline Hypotension & $3(18.8 \%)$ & 3 \\
\hline Procedural complications & $4(25.0 \%)$ & 4 \\
\hline Radiodermitis & $2(12.5 \%)$ & 2 \\
\hline Cardiac disorders & $3(18.8 \%)$ & 5 \\
\hline Eye disorders & $3(18.8 \%)$ & 3 \\
\hline Infections & $3(18.8 \%)$ & 3 \\
\hline Psychiatric disorders & $2(12.5 \%)$ & 2 \\
\hline
\end{tabular}

AEs: adverse events, N: number of, ALT: Alanine aminotransferase, AST: Aspartate aminotransferase.

radiotherapy and before chemotherapy, and three during the chemotherapy period [including one that received the 3 planned cycles]).

\section{Response and survival}

Four weeks after radiotherapy, 3 patients $(19 \%)$ had a PR, $6(38 \%)$ had a SD and 7 patients (43.8\%) had progressive disease (PD). No patients presented with CR. The proportion of patients with objective tumor response was therefore $19 \%$. At study closure, on 14 evaluated patients, there were 4 (29\%) PR, one SD (7\%; resulting in a disease control rate of $36 \%$ ), and 9 PD (64\%). The median TTP was 148 days (95\% confidence interval [CI]: 85 -not reached) and recurrence rate was $56 \%(n=9)$. No information on patterns of relapse was available.

At the time of the last contact (median follow-up of 2.1 years [range, 1.0-2.4 years]), 5 patients (31\%, including three that survived more than two years) were still alive resulting in a median OS of 11 months $(95 \% \mathrm{CI}$ : 5.9-27.7). In this study, 4 patients died during the study and 7 patients died after study withdrawal. Causes of death during the protocol were disease progression $(n=1)$ or adverse events ( $n=3$, cf. below). One-year PFS and OS rates were $31 \%$ (95\% CI: $14-56 \%)$ and $44 \%(95 \% \mathrm{CI}$ : 23-67\%), respectively (Figure 1). Smoking status did not correlate with survival outcomes. 
Table 3: Grade 3 or 4 AEs during the combination of gefitinib and radiotherapy (weeks 1 to 11)

$\begin{array}{llll}\text { Toxicity } & \text { Number of patients } & \text { AEs } & \text { Related to gefitinib-RT } \\ & \text { N }(\%) & \text { N } & \text { Number of patients }\end{array}$

$\begin{array}{ll}\text { Gastrointestinal disorders } & \mathbf{2 ( 1 2 . 5 \% )} \\ \text { Esophagitis } & 2(12.5 \%) \\ \text { General disorders } & \mathbf{2 ( 1 2 . 5 \% )} \\ \text { Fatigue } & 2(12.5 \%) \\ \text { General physical deterioration } & 1(6.3 \%) \\ \text { Investigations } & \mathbf{2 ( 1 2 . 5 \% )} \\ \text { ALT increased } & 1(6.3 \%) \\ \text { AST increased } & 1(6.3 \%) \\ \text { Hemoglobin decreased } & 1(6.3 \%) \\ \text { Respiratory disorders } & \mathbf{2 ( 1 2 . 5 \% )} \\ \text { Cough } & 1(6.3 \%) \\ \text { Dyspnea exacerbated } & 1(6.3 \%) \\ \text { Pneumonia } & 1(6.3 \%) \\ \text { Cardiac disorders } & \mathbf{1 ( 6 . 3 \% )} \\ \text { Atrioventricular block } & 1(6.3 \%) \\ \text { Procedural complications } & \mathbf{1 ( 6 . 3 \% )} \\ \text { Interstitial pneumonitis } & 1(6.3 \%) \\ \text { Metabolism and nutrition disorders } & \mathbf{1 ( 6 . 3 \% )} \\ \text { Dehydration } & 1(6.3 \%) \\ \text { Vascular disorders } & \mathbf{1 ( 6 . 3 \% )} \\ \text { Deep vein thrombosis } & 1(6.3 \%)\end{array}$

$\begin{array}{ll}\mathbf{2} & \mathbf{2} \\ 2 & 2 \\ \mathbf{2} & \mathbf{2} \\ 2 & 2 \\ 1 & 1 \\ \mathbf{2} & \mathbf{1} \\ 1 & 1 \\ 1 & 1 \\ 1 & 0 \\ \mathbf{2} & \mathbf{0} \\ 1 & 0 \\ 1 & 0 \\ 1 & 0 \\ \mathbf{1} & \mathbf{1} \\ 1 & 1 \\ \mathbf{1} & \mathbf{1} \\ 1 & 1 \\ \mathbf{1} & \mathbf{0} \\ 1 & 0 \\ \mathbf{1} & \mathbf{0} \\ 1 & 0\end{array}$

AEs: adverse events, N: number of, ALT: Alanine aminotransferase, AST: Aspartate aminotransferase, RT: radiotherapy. *Grade 5

\section{Toxicity}

During the experimental combination period, a total of 135 adverse events (AEs) were observed in the 16 patients evaluable, and 12 were $>$ grade $(\mathrm{G}) 3$ ( $9 \mathrm{G} 3$, two G4, and one G5; cf. Tables 3 \& 4). Most frequent AEs (all grades) were: gastrointestinal $(81 \%)$, cutaneous $(81 \%)$, general (56\%), and respiratory (50\%) (Table 2). The most common G3-4 AEs were: gastrointestinal $(n=2)$, general $(n=2)$, hematologic $(n=2)$ and respiratory $(n=2)$ (Table 3). Six patients had at least one serious adverse event (SAE); 2 of these patients had four SAEs. There were three possible adverse events-related deaths: one during the gefitinib-radiotherapy period (interstitial pneumonitis: $n=1$ ), and two after (pulmonary embolism at week 18, $n$ $=1$; sudden death within the hour after the administration of the $3^{\text {rd }}$ course of chemotherapy, $n=1$ ).

\section{DISCUSSION}

This trial was interrupted because of low accrual. The impact of Gefitinib ( $250 \mathrm{mg}$ daily) in combination with RT on outcomes in patients with locally advanced NSCLC then remains to be determined, especially in
$E G F R$ mutated patients (no EGFR mutated patients in our series). Previous clinical trials assessing gefitinib with irradiation did not include selected patients for $E G F R$ mutations (Table 4) [14-19]. In the largest experience reported by Ready et al, stage III NSCLC patients received gefitinib in combination with radiotherapy alone ("poor risk group": $n=21$ ), or with weekly paclitaxel and carboplatin ("good-risk group": $n=39$ ). Poor-risk group outcomes were promising with a median PFS and OS of 13.4 and 19.0 months, respectively (vs. 5 and 11 months in our study). The poorer outcomes reported in our study might be due to the different chemotherapy administration schedule or imaging modality used. Given the time-period of the study, 18FDG-PET and brain MRI were not mandatory for inclusion and may indeed have caused inadequate staging. It may likewise be difficult to differentiate local relapse and computed tomography changes correlating with radiation fibrosis after thoracic irradiation. Modern protocols generally integrate as ${ }^{18} \mathrm{~F}-\mathrm{FDG} \mathrm{PET} / \mathrm{CT}$, and a biopsy confirmation if a relapse is suspected. There are also data that EGFR wild-type patients could have a superior local control in comparison with mutated patients, however more distant metastases (no information on pattern of relapse in this study) [20, 21]. In Ready et al's experience, there was 
Table 4: Literature overview of concurrent anti-EGFR agents and radiotherapy

\begin{tabular}{|c|c|c|c|c|c|c|c|c|c|}
\hline Study & Phase & $\begin{array}{l}\text { Patients } \\
N\end{array}$ & $\begin{array}{l}\text { EGFR+ } \\
N(\%)^{*}\end{array}$ & $\begin{array}{l}\text { RT } \\
(G y)\end{array}$ & Chemotherapy & & $\begin{array}{l}\text { PFS } \\
(\text { med. } m)\end{array}$ & $\begin{array}{l}\mathrm{OS} \\
\text { (med.m) }\end{array}$ & $\begin{array}{l}\text { Toxicity } \geq G 4^{b} \\
(\%)\end{array}$ \\
\hline \multicolumn{10}{|c|}{ Gefitinib } \\
\hline Ready & II & PR:29 & $13(26)$ & 66 & PR: none & & \multirow{2}{*}{$\begin{array}{l}\text { PR: } 13.4 \\
\text { GR:9.2 }\end{array}$} & PR: 19 & PR:0 \\
\hline & & GR:21 & & & GR: Conc Ca Txl & & & GR: 13 & $\begin{array}{l}\text { GR: G5 pneumonitis ( } 8 \text { ) } \\
\text { G4 neutrop ( } 36)\end{array}$ \\
\hline Niho & II & 38 & NS & 60 & Ind CDDP Vin & & 11.2 & 28.5 & G4 HLE increase (6) \\
\hline Stinchcombe & II & 23 & NS & 74 & $\begin{array}{l}\text { Ind } \mathrm{Ca} \text { Txl Iri } \\
\text { Conc Ca Txl }\end{array}$ & & 9 & 16 & $\begin{array}{l}\text { G4 embolism ( } 4.8) \\
\text { G4 thrombopenia (4.8) }\end{array}$ \\
\hline Okamoto & II & 9 & $2(29)$ & 60 & None & & NS & NS & None \\
\hline Center & I & 16 & NS & 70 & Conc + Cons Txt & & \multirow{2}{*}{$\begin{array}{l}7.1 \\
6 \mathrm{~m}: 42.9 \%\end{array}$} & 21 & G5 pneumonitis (13) \\
\hline Rothschild & I & $\begin{array}{l}\text { Step 1: } 9 \\
\text { Step 2: } 5\end{array}$ & NS & 63 & $\begin{array}{l}\text { Step } 1: \text { none } \\
\text { Step } 2: \text { CDDP }\end{array}$ & & & $6 \mathrm{~m}: 85.7 \%$ & G4 dyspnea (7) \\
\hline Current & II & 16 & 0 & 66 & Cons CDDP Vin & & \multicolumn{2}{|r|}{11} & $\begin{array}{l}\text { G5 pneumonitis (6.3) } \\
\text { G4 pneumonia (6.3) } \\
\text { G4 dehydration }(6.3)\end{array}$ \\
\hline \multicolumn{10}{|c|}{ Erlotinib } \\
\hline Lilenbaum & II & 75 & 0 & 66 & Ind $\mathrm{Ca}$ nab-Txl & & 11 & 17 & $\begin{array}{l}\text { G4 blood (8) } \\
\text { G4 fatigue (1) }\end{array}$ \\
\hline Komaki & II & 48 & $4(8)$ & 63 & Conc + Cons Ca Txl & & \multirow{2}{*}{$\begin{array}{l}14 \\
10.2\end{array}$} & 36.5 & G4 pneumonitis (2) \\
\hline Socinski & $\mathrm{I} / \mathrm{II}$ & 45 & NS & 74 & $\begin{array}{l}\text { Ind+Conc Ca Txl Bev } \\
+ \text { Cons Bev } \\
\text { Cetuximab }\end{array}$ & & & 18.4 & $\begin{array}{l}\text { G4 neutrop (18) } \\
\text { G4 esophagitis (2) }\end{array}$ \\
\hline Bradley & III & $\begin{array}{l}147 \\
110\end{array}$ & NS & $\begin{array}{l}60 \\
74\end{array}$ & $\begin{array}{l}\text { Conc }+ \text { Cons } \mathrm{Ca} \text { Txl } \\
\text { idem }\end{array}$ & & 10.8 & 25 & $\begin{array}{l}\text { G4 blood (46) } \\
\text { G4/5 dyspnea (2) } \\
\text { G4 pneumonitis (1) } \\
\text { G4 dehydration (2) } \\
\text { G4 dysphagia (1) }\end{array}$ \\
\hline Blumenschein $^{\mathrm{a}}$ & II & 93 & NS & 63 & Conc + Cons $\mathrm{Ca} \mathrm{Txl}$ & & $2 y$ FR : $44.8 \%$ & 22.7 & $\begin{array}{l}\text { G5 pneumonitis (2) } \\
\text { G5 ARDS (1) }\end{array}$ \\
\hline Hallqvist & II & 75 & NS & 68 & Ind CDDP Txt & & NS & 17 & $\begin{array}{l}\text { G5 pneumonitis (1.4) } \\
\text { G4 hypersens }(2.8)\end{array}$ \\
\hline Ramalingam & II & 40 & NS & 73.5 & Cons Ca Txl & & 9.3 & 19.4 & $\begin{array}{l}\text { G4 infection } \\
\text { G4 infusion reaction } \\
\text { G4 embolism } \\
\text { G4 feb neutrop }(9.8)\end{array}$ \\
\hline Govidan & II & 53 & NS & 70 & Conc $\mathrm{Ca}$ Pem & 12.3 & \multicolumn{2}{|l|}{25.2} & $\begin{array}{l}\text { G5 pneumonitis (4) } \\
\text { G5 embolism (2) }\end{array}$ \\
\hline
\end{tabular}

N: number of; EGFR+ : epidermal growth factor receptor mutation; RT: radiotherapy; Conc: concurrent; Cons: Consolidation (post-RT); med. m: median months; PR: poor risk: GR: good risk; Ca: carboplatin: Txl: paclitaxel; Txt: docetaxel; Vin: vinorelbine; Bev: bevacizumab; Pem: pemetrexed; 6m: 6 month; neutrop: neutropenia; hypersens: hypersensitivity; HLE: hepatic liver enzymes; feb: febrile; ARDS: Acute respiratory distress syndrome; FR: failure rate; y: year; NS: not stated.

*Only genomic analyses are reported

a Only G5 are reported here for this study

b Only the concurrent period is generally reported

no apparent survival difference with $E G F R$-activating mutations (13/45 available tumors, including 2 who had also $T 790 M$ mutations) vs. wild type or $K R A S$ mutation [17]. On the other hand, we recently reported in 78 stage IIIA/IIIB NSCLC patients who received irradiation, that selected gene alterations could be associated with a poorer PFS. The EGFR/ALK (EML4-anaplastic lymphoma kinase) group and patients with any other mutations $(n=$ 28) had a poorer PFS (median 9.6 and 6.0 months; $p=$ $0.005)$ compared to the wild-type group $($ median $=12.0$ months) [22]. Anyway, the question of whether certain gene alterations could be predictive of radio-sensitivity or radio-resistance remains debated.

The combination of gefitinib and radiotherapy was mild. The most common G3-4 AEs were: gastrointestinal $(n=2)$, general $(n=2)$, hematologic $(n=$ 2 ) and respiratory $(n=2)$. In our trial, chemotherapy was delivered sequentially because concomitant administration of chemoradiotherapy and gefitinib could have been much more toxic. The triple combination of bioradiotherapy and chemotherapy may lead to unexpected toxicities [23]. The authors were quite cautious since pulmonary toxicity (interstitial pneumonia or interstitial lung disease) had been reported in stage IV NSCLC, and this may occur more frequently in the Asian population [24, 25]. In other studies, concurrent weekly cisplatin likely enhanced toxicity [12] but weekly paclitaxel-carboplatin did not [17]. Rotschild et al, observed 2 dose-limiting toxicities (DLT) in 9 patients $(22.2 \%)$ receiving concurrent weekly cisplatin, whereas no DLT occurred in the 5 patients without concomitant chemotherapy. DLT consisted of a G3 pulmonary infection (and thus related to a G4 infection dyspnea), and of a G2 increase in hepatic enzymes.

In our trial, one patient died from an acute interstitial pneumonitis. Others have reported severe interstitial pneumonitis with concurrent irradiation-gefitinib (or other anti-EGFR, Table 4). New available radiotherapy techniques such as IMRT or respiratory gating could help 
delivering smaller irradiated volumes / sparing organ at risk from higher radiation doses $[26,27]$. Though IMRT may be damaging to lung because of low-dose bath. Constraints of normal irradiated lung were, in this study, less tight than recommended nowadays (volume of normal lung minus the planned target volume [PTV] receiving at least 20 Gy $(\mathrm{V} 20)<40 \%$ ). This must be emphasized for the conception of new trials, since any loosening in radiotherapy constraints, especially to the lung but also to the heat, may alter the safety of the combination as shown in the recently published RTOG (Radiation Therapy Oncology Group) trial [28].

Of note, concurrent erlotinib and whole brain radiotherapy (WBRT) have also been prospectively studied in brain metastatic NSCLC patients with a good overall response rate $(86 \%)$ and no increased neurotoxicity [29]. A randomized study still did not show survival advantage for concurrent erlotinib and WBRT followed by maintenance erlotinib in patients with predominantly EGFR wild-type NSCLC as compared to placebo [30].

Additional anti-EGFR treatments [14-19, 28, 3137] and other newer molecular compounds [38] are tested with concomitant radiation in this setting (Table 4). In the only phase III trial [28], the anti-EGFR cetuximab associated to chemoradiotherapy lead to higher toxic effects but did not increase OS in unselected NSCLC stage III patients. Further experiences evaluating concomitant erlotinib with chemoradiation were also disappointing [31-33]. The RTOG 1306 II trial is currently recruiting patients with mutations in EGFR and/or $A L K$ fusion arrangement who receive induction erlotinib or crizotinib before thoracic chemoradiotherapy. Finally, as some of the effects of ionizing radiation are now recognized as contributing to antitumor immunity [39, 40], targeting molecules that downregulate the $\mathrm{T}$ cell immune response with immunotherapy such as antiCTLA-4 (cytotoxic T-lymphocyte antigen-4) or antiPD-1/PD-L1 (programmed death-1 and it ligands) are also currently assessed in patients with locally advanced NSCLC receiving definitive radiotherapy (NCT02125461, NCT02434081, NCT02400814).

\section{CONCLUSION}

In this phase II trial, gefitinib (250mg once daily) in combination with thoracic radiotherapy administered with conventional fractionation at the dose of 66 Gy followed by chemotherapy in previously untreated stage III NSCLC was feasible but lead to substantial toxicities (one toxic death during the concomitant period and two possible adverse events-related deaths during the chemotherapy period). Due to premature trial discontinuation and the absence of patients with EGFR mutated NSCLC, our results should be cautiously interpreted. Further investigation is needed to better assess the therapeutic ratio of this combination in trials that take into account modern radiation-delivery techniques and incorporate the biological abnormalities of tumors (EGFR mutated NSCLC).

\section{CONFLICTS OF INTEREST}

Authors have no conflict of interest to declare.

\section{FUNDING}

This trial has been sponsored by AstraZeneca. The funders of the study had no role in the writing of the report. The corresponding author had full access to all the data in the study and had final responsibility for the decision to submit for publication.

This work was presented at the $16^{\text {th }}$ World Conference on Lung Cancer (WCLC 2015)

\section{Author contributions}

AL, BL, JPP, JA, LL, and CLP analyzed the data $\mathrm{AL}, \mathrm{BL}, \mathrm{JPP}$, and CLP wrote the manuscript All authors reviewed and approved the paper ClinicalTrials.gov identifier: NCT00333294

\section{REFERENCES}

1. Aupérin A, Le Péchoux C, Pignon JP, Koning C, Jeremic B, Clamon G, Einhorn L, Ball D, Trovo MG, Groen HJ, Bonner JA, Le Chevalier T, Arriagada R; MetaAnalysis of Cisplatin/carboplatin based Concomitant Chemotherapy in non-small cell Lung Cancer (MAC3-LC) Group. Concomitant radio-chemotherapy based on platin compounds in patients with locally advanced non-small cell lung cancer (NSCLC): a meta-analysis of individual data from 1764 patients. Ann Oncol. 2006; 17:473-83.

2. O'Rourke N, Roqué I Figuls M, Farré Bernadó N, Macbeth F. Concurrent chemoradiotherapy in non-small cell lung cancer. Cochrane Database Syst Rev. 2010; CD002140.

3. Le Pechoux C, Burdett S, Auperin A. Individual patient data (IPD) meta-analyses (MA) of chemotherapy (CT) in locally advanced non-small cell lung cancer (NSCLC). 1st European Lung Cancer Conference, Geneva, April 2008. J Thorax Oncol 2008;3: S20.

4. Shi Y, Au JS, Thongprasert S, Srinivasan S, Tsai CM, Khoa MT, Heeroma K, Itoh Y, Cornelio G, Yang PC. A prospective, molecular epidemiology study of EGFR mutations in Asian patients with advanced non-small-cell lung cancer of adenocarcinoma histology (PIONEER). J Thorac Oncol. 2014; 9:154.

5. Lee CK, Brown C, Gralla RJ, Hirsh V, Thongprasert S, Tsai CM, Tan EH, Ho JC, Chu da T, Zaatar A, Osorio Sanchez JA, $\mathrm{Vu} \mathrm{VV}, \mathrm{Au}$ JS, et al. Impact of EGFR inhibitor in non-small cell lung cancer on progression-free and overall 
survival: a meta-analysis. J Natl Cancer Inst. 2013; 105:595.

6. Mok TS, Wu YL, Thongprasert S, Yang CH, Chu DT, Saijo N, Sunpaweravong P, Han B, Margono B, Ichinose Y, Nishiwaki Y, Ohe Y, Yang JJ, et al. Gefitinib or carboplatin-paclitaxel in pulmonary adenocarcinoma. N Engl J Med. 2009;361:947.

7. Maemondo M, Inoue A, Kobayashi K, Sugawara S, Oizumi S, Isobe H, Gemma A, Harada M, Yoshizawa H, Kinoshita I, Fujita Y, Okinaga S, Hirano H, Yoshimori K, et al.; North-East Japan Study Group. Gefitinib or chemotherapy for non-small-cell lung cancer with mutated EGFR. N Engl J Med. 2010;362:2380.

8. Tanaka T, Munshi A, Brooks C, Liu J, Hobbs ML, Meyn RE. Gefitinib radiosensitizes non-small cell lung cancer cells by suppressing cellular DNA repair capacity. Clin Cancer Res. 2008;14:1266-73.

9. Bonner JA, Harari PM, Giralt J, Cohen RB, Jones CU, Sur RK, Raben D, Baselga J, Spencer SA, Zhu J, Youssoufian H, Rowinsky EK, Ang KK. Radiotherapy plus cetuximab for locoregionally advanced head and neck cancer: 5-year survival data from a phase 3 randomised trial, and relation between cetuximab-induced rash and survival. Lancet Oncol. 2010;11:21-8.

10. Fournel P, Robinet G, Thomas P, Souquet PJ, Léna H, Vergnenégre A, Delhoume JY, Le Treut J, Silvani JA, Dansin E, Bozonnat MC, Daurés JP, Mornex F, et al; Groupe Lyon-Saint-Etienne d'Oncologie ThoraciqueGroupe Français de Pneumo-Cancérologie. Randomized phase III trial of sequential chemoradiotherapy compared with concurrent chemoradiotherapy in locally advanced non-small-cell lung cancer: Groupe Lyon-SaintEtienne d'Oncologie Thoracique-Groupe Français de Pneumo-Cancérologie NPC 95-01 Study. J Clin Oncol. 2005;23:5910-7.

11. Curran WJ Jr, Paulus R, Langer CJ, Komaki R, Lee JS, Hauser S, Movsas B, Wasserman T, Rosenthal SA, Gore E, Machtay M, Sause W, et al. Sequential vs. concurrent chemoradiation for stage III non-small cell lung cancer: randomized phase III trial RTOG 9410. J Natl Cancer Inst. 2011;103:1452-60.

12. De Martino MC, Al Ghuzlan A, Aubert S, Assié G, Scoazec JY, Leboulleux S, Do Cao C, Libè R, Nozières C, Lombès M, Pattou F, Borson-Chazot F, et al. Molecular screening for a personalized treatment approach in advanced adrenocortical cancer. J Clin Endocrinol Metab. 2013;98:4080-8.

13. Schemper M, Smith TL. A note on quantifying follow-up in studies of failure time. Control Clin Trials. 1996; 17: 343-6.

14. Rothschild S, Bucher SE, Bernier J, Aebersold DM, Zouhair A, Ries G, Lombrieser N, Lippuner T, Lütolf UM, Glanzmann C, Ciernik IF. Gefitinib in combination with irradiation with or without cisplatin in patients with inoperable stage III non-small cell lung cancer: a phase I trial. Int J Radiat Oncol Biol Phys. 2011; 80:126-32.

15. Center B, Petty WJ, Ayala D, Hinson WH, Lovato J,
Capellari J, Oaks T, Miller AA, Blackstock AW. A phase I study of gefitinib with concurrent dose-escalated weekly docetaxel and conformal three-dimensional thoracic radiation followed by consolidative docetaxel and maintenance gefitinib for patients with stage III non-small cell lung cancer. J Thorac Oncol. 2010; 5:69-74.

16. Okamoto I, Takahashi T, Okamoto H, Nakagawa K, Watanabe K, Nakamatsu K, Nishimura Y, Fukuoka M, Yamamoto N. Single-agent gefitinib with concurrent radiotherapy for locally advanced non-small cell lung cancer harboring mutations of the epidermal growth factor receptor. Lung Cancer. 2011; 72:199-204.

17. Ready N, Jänne PA, Bogart J, Dipetrillo T, Garst J, Graziano S, Gu L, Wang X, Green MR, Vokes EE; Cancer, Leukemia Group B, Chicago, IL. Chemoradiotherapy and gefitinib in stage III non-small cell lung cancer with epidermal growth factor receptor and KRAS mutation analysis: cancer and leukemia group B (CALGB) 30106, a CALGB-stratified phase II trial. J Thorac Oncol. 2010;5:1382-90.

18. Niho S, Ohe Y, Ishikura S, Atagi S, Yokoyama A, Ichinose Y, Okamoto H, Takeda K, Shibata T, Tamura T, Saijo N, Fukuoka M. Induction chemotherapy followed by gefitinib and concurrent thoracic radiotherapy for unresectable locally advanced adenocarcinoma of the lung: a multicenter feasibility study (JCOG 0402). Ann Oncol 2012;23:2253-8.

19. Stinchcombe TE, Morris DE, Lee CB, Moore DT, Hayes DN, Halle JS, Rivera MP, Rosenman JG, Socinski MA. Induction chemotherapy with carboplatin, irinotecan, and paclitaxel followed by high dose three-dimension conformal thoracic radiotherapy (74 Gy) with concurrent carboplatin, paclitaxel, and gefitinib in unresectable stage IIIA and stage IIIB non-small cell lung cancer. J Thorac Oncol. 2008;3:250-7.

20. Tanaka K, Hida T, Oya Y, Oguri T, Yoshida T, Shimizu J, Horio Y, Hata A, Kaji R, Fujita S, Sekido Y, Kodaira $\mathrm{T}$, et al. EGFR Mutation Impact on Definitive Concurrent Chemoradiation Therapy for Inoperable Stage III Adenocarcinoma. J Thorac Oncol. 2015;10:1720-5.

21. Yagishita S, Horinouchi H, Katsui Taniyama T, Nakamichi S, Kitazono S, Mizugaki H, Kanda S, Fujiwara Y, Nokihara H, Yamamoto N, Sumi M, Shiraishi K, Kohno T, et al. Epidermal growth factor receptor mutationis associated with longer local control after definitive chemoradiotherapy in patients with stage III nonsquamous non-small-cell lung cancer. Int J Radiat Oncol Biol Phys. 2015;91:140-8.

22. Boros A, Lacroix L, Lacas B, Adam J, Pignon JP, Caramella C, Caramella C, Planchard D, Levy A, De Montpreville V, Deutsch E, Besse B, Le Pechoux C. Mutation Profile Prognostic Value in Stage III Non Small Cell Lung Cancer (NSCLC) Patients Treated with Chemo-Radiotherapy (CRT). Eur J Cancer 2015. 205; S3: S595.

23. Deutsch E, Lemanski C, Pignon JP, Levy A, Delarochefordiere A, Martel-Lafay I, Rio E, Malka D, Conroy T, Miglianico L, Becouarn Y, Malekzadeh K, 
Paris E, et al. Unexpected toxicity of cetuximab combined with conventional chemoradiotherapy in patients with locally advanced anal cancer: results of the UNICANCER ACCORD 16 phase II trial. Ann Oncol. 2013;24:2834-8.

24. Inoue A, Saijo Y, Maemondo M, Gomi K, Tokue Y, Kimura Y, Ebina M, Kikuchi T, Moriya T, Nukiwa T. Severe acute interstitial pneumonia and gefitinib. Lancet 2003; 361: 1379.

25. Kudoh S, Kato H, Nishiwaki Y, Fukuoka M, Nakata K, Ichinose Y, Tsuboi M, Yokota S, Nakagawa K, Suga M; Japan Thoracic Radiology Group, Jiang H, Itoh Y, Armour A, et al. Interstitial lung disease in Japanese patients with lung cancer: a cohort and nested case-control study. Am J Respir Crit Care Med 2008; 177: 134813488

26. Jiang ZQ, Yang K, Komaki R, Wei X, Tucker SL, Zhuang Y, Martel MK, Vedam S, Balter P, Zhu G, Gomez D, Lu C, Mohan R, et al. Long-term clinical outcome of intensitymodulated radiotherapy for inoperable non-small cell lung cancer: the MD Anderson experience. Int J Radiat Oncol Biol Phys. 2012;83:332-9.

27. Giraud P, Morvan E, Claude L, Mornex F, Le Pechoux C, Bachaud JM, Boisselier P, Beckendorf V, Morelle M, Carrère MO; STIC Study Centers. Respiratory gating techniques for optimization of lung cancer radiotherapy. $\mathrm{J}$ Thorac Oncol. 2011;6:2058-68.

28. Bradley JD, Paulus R, Komaki R, Masters G, Blumenschein G, Schild S, Bogart J, Hu C, Forster K, Magliocco A, Kavadi V, Garces YI, Narayan S, et al. Standard-dose versus high-dose conformal radiotherapy with concurrent and consolidation carboplatin plus paclitaxel with or without cetuximab for patients with stage IIIA or IIIB nonsmall-cell lung cancer (RTOG 0617): a randomised, twoby-two factorial phase 3 study. Lancet Oncol. 2015;16:18799.

29. Lee SM, Lewanski CR, Counsell N, Ottensmeier C, Bates A, Patel N, Wadsworth C, Ngai Y, Hackshaw A, FaivreFinn C. Randomized trial of erlotinib plus whole-brain radiotherapy for NSCLC patients with multiple brain metastases. J Natl Cancer Inst. 2014;106. pii: dju151.

30. Welsh JW, Komaki R, Amini A, Munsell MF, Unger W, Allen PK, Chang JY, Wefel JS, McGovern SL, Garland LL, Chen SS, Holt J, Liao Z, et al. Phase II trial of erlotinib plus concurrent whole-brain radiation therapy for patients with brain metastases from non-small-cell lung cancer. J Clin Oncol. 2013;31:895-902.

31. Socinski MA, Stinchcombe TE, Moore DT, Gettinger SN, Decker RH, Petty WJ, Blackstock AW, Schwartz G, Lankford S, Khandani A, Morris DE. Incorporating bevacizumab and erlotinib in the combined-modality treatment of stage III non-small-cell lung cancer: Results of a phase I/II trial. J Clin Oncol 2012;30:3953-3959.

32. Komaki R, Allen PK, Wei X, Blumenschein GR, Tang X, Lee JJ, Welsh JW, Wistuba II, Liu DD, Hong WK. Adding Erlotinib to Chemoradiation Improves Overall Survival but Not Progression-Free Survival in Stage III Non-Small Cell
Lung Cancer. Int J Radiat Oncol Biol Phys. 2015;92:31724.

33. Lilenbaum R, Samuels M, Wang X, Kong FM, Jänne PA, Masters G, Katragadda S, Hodgson L, Bogart J, Bradley J, Vokes E. A phase II study of induction chemotherapy followed by thoracic radiotherapy and erlotinib in poorrisk stage III non-small-cell lung cancer: results of CALGB 30605 (Alliance)/RTOG 0972 (NRG). J Thorac Oncol. 2015;10:143-7.

34. Blumenschein GR Jr, Paulus R, Curran WJ, Robert F, Fossella F, Werner-Wasik M, Herbst RS, Doescher PO, Choy H, Komaki R. Phase II study of cetuximab in combination with chemoradiation in patients with stage IIIA/B non-small-cell lung cancer: RTOG 0324. J Clin Oncol. 2011;29:2312-8.

35. Hallqvist A, Wagenius $\mathrm{G}$, Rylander $\mathrm{H}$, Brodin $\mathrm{O}$, Holmberg E, Lödén B, Ewers SB, Bergström S, WichardtJohansson G, Nilsson K, Ekberg L, Sederholm C, Nyman J. Concurrent cetuximab and radiotherapy after docetaxelcisplatin induction chemotherapy in stage III NSCLC: satellite--a phase II study from the Swedish Lung Cancer Study Group. Lung Cancer. 2011;71:166-72.

36. Ramalingam SS, Kotsakis A, Tarhini AA, Heron DE, Smith R, Friedland D, Petro DP, Raez LE, Brahmer JR, Greenberger JS, Dacic S, Hershberger P, Landreneau RJ, et al. A multicenter phase II study of cetuximab in combination with chest radiotherapy and consolidation chemotherapy in patients with stage III non-small cell lung cancer. Lung Cancer. 2013;81:416-21.

37. Govindan R, Bogart J, Stinchcombe T, Wang X, Hodgson L, Kratzke R, Garst J, Brotherton T, Vokes EE. Randomized phase II study of pemetrexed, carboplatin, and thoracic radiation with or without cetuximab in patients with locally advanced unresectable non-small-cell lung cancer: Cancer and Leukemia Group B trial 30407. J Clin Oncol. 2011;29:3120-5.

38. Deutsch E, Le Péchoux C, Faivre L, Rivera S, Tao Y, Pignon JP, Angokai M, Bahleda R, Deandreis D, Angevin E, Hennequin C, Besse B, Levy A, et al. Phase I trial of everolimus in combination with thoracic radiotherapy in non-small-cell lung cancer. Ann Oncol. 2015;26:1223-9.

39. Levy A, Chargari C, Cheminant M, Simon N, Bourgier C, Deutsch E. Radiation therapy and immunotherapy: implications for a combined cancer treatment. Crit Rev Oncol Hematol. 2013;85:278-87.

40. Levy A, Chargari C, Marabelle A, Perfettini JL, Magné N, Deutsch E. Can immunostimulatory agents enhance the abscopal effect of radiotherapy? Eur J Cancer 2016;62:3645. 